\title{
Lysosomal storage diseases
}

\author{
Smitha Rose Georgy ${ }^{1}$ \\ Faculty of Veterinary and Agricultural Sciences, 250 Princess Highway, Werribee, \\ The University of Melbourne, Victoria 3030 Australia
}

Citation: Georgy, S.R. 2021. Lysosomal storage diseases. J. Vet. Anim. Sci. 52(1): 1-6.

DOI: https://doi.org/10.51966/jvas.2021.52.1.1-6

Received : 17.11.2020

Accepted: 28.11.2020

Published: 01.01.2021

\section{Abstract}

Lysosomes play a pivotal role in cellular processes through an active interplay of enzymes, lysosomal membrane proteins, and cytosolic proteins. Lysosomal storage diseases are a group of inherited and acquired disorders. Clinically affected animals are presented with developmental and neurological symptoms. This review aims to discuss the function of lysosomes, the pathogenesis of lysosomal storage disease, and its diagnosis.

\section{Lysosomal structure and function}

Lysosomes are membrane-bound cytoplasmic organelles present in most vertebrate cells, invertebrates, and unicellular organisms. Its primary function is to dispose of and recycle cellular contents. Lysosomes function as the "intracellular digestive tract" and contain a battery of hydrolytic enzymes that aids in digestion and a special category of secretory proteins that are destined for intracellular organelles (Kumar et al., 2015).

Lysosomes contain approximately 50 different acid hydrolases including proteases, nucleases, lipases, glycosidases, phosphatases, and sulfatases that are active in an acidic $\mathrm{pH}$ in the 4.5 to 5 range, but not at the neutral pH (about 7.2) characteristic of the rest of the cytoplasm (Saftig and Klumperman, 2009). These enzymes are synthesized in the endoplasmic reticulum and transported to the Golgi apparatus. These enzymes undergo a variety of post-translational modifications within the Golgi complex, including attachment of phosphorylated mannose residues, that serves as an address label and are segregated as lysosomal enzymes. Subsequently, small transport vesicles containing lysosomal enzymes are pinched off from the Golgi and proceed to fuse with the lysosomes (Luzio et al., 2007). Genetically determined errors in this sorting mechanism may give rise to one form of lysosomal storage disease.

\section{Lysosomal storage disease - pathogenesis}

A variety of complex macromolecules are broken down by lysosomal enzymes. How cells accumulate these macromolecules? There are two processes from which these macromolecules are derived within the cell namely autophagy and heterophagy (Marques and Saftig, 2019). Autophagy is a cell survival mechanism, in which a cell eats its contents. The cytoplasmic materials

1. Lecturer in Veterinary Pathology, Email id : s.georgy@unimelb.edu.au

Copyright: (C) 2021 Smitha. This is an open access article distributed under the terms of the Creative Commons Attribution 4.0 International License (http://creativecommons.org/licenses/by/4.0/), which permits unrestricted use, distribution, and reproduction in any medium, provided the original author and source are credited. 
to be recycled are delivered to the lysosome for degradation. Whereas in heterophagy, the lysosomes fuse with endosomes or phagosomes to facilitate the degradation of internalized contents. If there is any deficiency of the lysosomal enzymes, it gives rise to two pathological consequences. 1) accumulation of partially degraded insoluble metabolite within the lysosomes, called primary accumulation, 2) accumulation of autophagic substrates because of impaired lysosomal function within the cytoplasm, called secondary accumulation (Kumar et al., 2015) (Figure 1). This will eventually lead to the accumulation of toxic proteins, generation of free radicals, damage to the plasma membrane leading to cell death. Any dysfunction of the lysosomal catabolic pathway results in the accumulation of macromolecules within the cells leading to lysosomal storage disease (Ballabio and Gieselmann, 2009). The severity of the disease is partially depending on the type of accumulating waste product. Approximately 51 lysosomal storage diseases are reported in humans and many of them are also reported in animals. Many different cell types and tissues are affected by lysosomal storage disorders and the involvement of the tissue varies at different stages of the disease process. The tissues commonly affected include the liver, spleen, bone and joint, eye, adrenal gland, cardiac and skeletal muscle, and brain (Ferreira and Gahl, 2017). In affected animals, brain lesions are particularly prevalent, and more than two-thirds of lysosomal storage disease exhibit neurological signs (Walkley, 2009).

\section{Classification of lysosomal storage disease}

Lysosomal storage disease can be categorized based upon the macromolecule that is abnormally stored in the cells and examples include carbohydrates (Pompe disease), neutral lipids (Wolman disease), and sphingolipids (Niemann- Pick disease) (Ferreira and Gahl, 2017). Inherited defects in the degradation of sphingolipids are one of the major categories of lysosomal disease and it particularly affects the nervous system (Jolly and Walkley, 1997). One of the byproducts of sphingolipid catabolism is ganglioside and it
Fig 1: Pathogenesis of lysosomal storage diesease (Kumar et al., 2015)

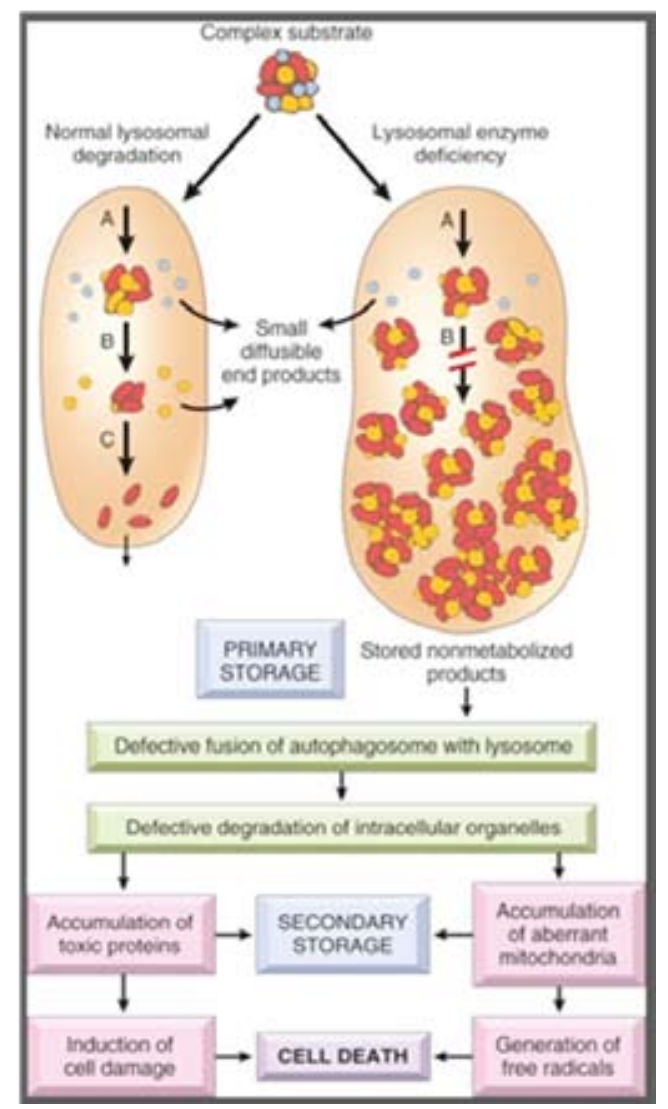

accumulates when there is a deficiency of the enzyme $\beta$ galactosidase leading to generalized gangliosidosis. This disorder is described in Siamese cats, English springer spaniel, and rarely in German short-haired pointer. Clinical signs are exhibited by 2 to 4 months of age and include vision problems, lethargy, difficulty in walking and death occurs by 8 months (Skelly and Franklin, 2002).

\begin{abstract}
Lysosomal storage disease can be
categorized based on the cause as inherited or acquired. The deficiency of lysosomal enzymes is inherited in an autosomal recessive pattern and usually involves a single enzyme deficiency. Affected animals are usually normal at birth, and in most cases, the symptoms develop in the first year of life. The severity of the disease is determined by the level of the enzyme. When enzyme activity is less than $15 \%$ of the normal level, the accumulation of undegraded substrate occurs. Selected inherited lysosomal
\end{abstract}


storage diseases are given in table 1.

Acquired disorders could result from inhibition of a-mannosidase II by ingestion of plant materials or treatment with certain drugs. Chronic ingestion of legumes of the genera Astragulus and Oxytropis inhibit a-mannosidase II causing cells to accumulate oligosaccharides. This results in systemic lysosomal storage disease manifesting microscopically as clear cytoplasmic vacuoles in multiple organs including neurons of the brain (Alroy and Lyons, 2014). Neuronal vacuolation is seen in approximately two-thirds of all lysosomal storage diseases. The drugs leading to the acquired disease include amiodarone and chloroquine.

\section{Diagnosis}

Lysosomal storage disease affects males and females with equal frequency. Accumulation of the substrate within cells leads to cellular dysfunction either directly or indirectly. The clinical signs reflect the abundance of the substrate within the cells and the link between storage and clinical signs is poorly understood. Lysosomal storage disease should be among the differential diagnoses when an animal is presented with multifocal neurological disease. Animals may show a change in behavior, ataxia, proprioceptive deficits, apparent blindness, deafness, and seizures. These signs are prevalent in the early stages of gangliosidosis in cats and dogs (Alroy et al., 1985; De Maria et

Table1: Selected inherited lysosomal storage disease

\begin{tabular}{|c|c|c|c|}
\hline Condition & Enzyme Defect & Storage Material & Species \\
\hline $\mathrm{G}_{\mathrm{M} 1}$ gangliosidosis & $\beta$-galactosidase & $\begin{array}{l}\mathrm{G}_{\mathrm{M} 1} \text { ganglioside in } \\
\text { neurons, glial cells, } \\
\text { macrophages }\end{array}$ & \begin{tabular}{|l} 
Dogs \\
Cats \\
Friesian cattle \\
Suffolk sheep
\end{tabular} \\
\hline $\mathrm{G}_{\mathrm{M} 2}$ gangliosidosis & Hexaminidase & $\begin{array}{l}\mathrm{G}_{\mathrm{M} 2} \text { ganglioside in } \\
\text { neurons, glial cells, } \\
\text { macrophages }\end{array}$ & $\begin{array}{l}\text { Cats } \\
\text { German shorthaired } \\
\text { pointer } \\
\text { Golden retriever } \\
\text { Japanese Spaniel } \\
\text { Yorkshire pigs } \\
\end{array}$ \\
\hline Sphingomyelinosis & Sphingomyelinase & $\begin{array}{l}\text { Sphingomyelin } \\
\text { in neurons and } \\
\text { macrophages }\end{array}$ & $\begin{array}{l}\text { Dogs } \\
\text { Cats }\end{array}$ \\
\hline $\begin{array}{l}\text { Globoid cell } \\
\text { leukodystrophy }\end{array}$ & Galactocerebrosidase & $\begin{array}{l}\text { Galactocerebrosides } \\
\text { in oligodendrocytes, } \\
\text { Schwann cells, } \\
\text { macrophages } \\
\end{array}$ & $\begin{array}{l}\text { Dogs } \\
\text { Cats } \\
\text { Polled Dorset Sheep }\end{array}$ \\
\hline Glucocerebrosidosis & Glucocerebrosidase & $\begin{array}{l}\text { Glucosylceramide } \\
\text { in kupffer cells and } \\
\text { neurons }\end{array}$ & Dogs- Silky terrier \\
\hline a Mannosidosis & a Mannosidase & $\begin{array}{l}\text { Mannose } \\
\text { oligosaccharide } \\
\text { in neurons, } \\
\text { macrophages, and } \\
\text { secretory epithelial } \\
\text { cells }\end{array}$ & Cattle \\
\hline$\beta$ Mannosidosis & $\beta$-mannosidase & $\begin{array}{l}\text { Oligosaccharide } \\
\text { in neurons, } \\
\text { macrophages, and } \\
\text { secretory epithelial } \\
\text { cells }\end{array}$ & $\begin{array}{l}\text { Cattle } \\
\text { Goat }\end{array}$ \\
\hline Mucopolysaccharidosis & $\begin{array}{l}\text { Iduronidase } \\
\text { Sulfaminidase }\end{array}$ & $\begin{array}{l}\text { Dermatan sulfate } \\
\text { Heparan sulfate }\end{array}$ & $\begin{array}{l}\text { Cats } \\
\text { Dogs } \\
\text { Goats } \\
\end{array}$ \\
\hline
\end{tabular}


al., 1998], globoid cell leukodystrophy (Wenger et al., 1999), and in feline a-mannosidosis (Jezyk et al., 1986).

\section{Clinical pathology}

In most cases the haematological and routine biochemical assessment is unremarkable. The presence of storage vacuoles within leukocytes during blood smear evaluation can be informative in some cases. However, examination of cells from several different tissues may be required to demonstrate the presence of the storage material. If a storage disease is suspected, and if the peripheral blood smear is unremarkable, lymphoid tissues including spleen can show evidence of vacuolation. Hence lymph node biopsies and aspirates can be diagnostically helpful. In animals showing hepatomegaly, liver aspirates or needle biopsies can be useful in identifying the storage material.

\section{Radiography}

A radiographic examination can reveal bony malformations in lysosomal storage disease. Animals with mucopolysaccharidosis do exhibit bone and connective tissue abnormalities and include facial deformities such as frontal bossing of the skull and facial deformity. Pain, gait abnormalities, and a history of fracture are reported in cases of lysosomal storage disease.

\section{Cerebrospinal fluid analysis}

Cerebrospinal fluid examination of patients with altered neurological function is part of their normal investigation. In cases of globoid cell leukodystrophy and fucosidosis, cerebrospinal fluid analysis may display vacuolated macrophages or lymphocytes containing storage materials (Skelly and Franklin, 2002).

\section{Biopsy}

Muscle biopsy, peripheral nerve biopsy, and electron microscopy of the skin can add to the diagnosis [Skelly and Franklin,2002; Alroy and Ucci, 2006]. Peripheral nerve biopsy is used frequently to diagnose globoid cell leukodystrophy (Vicini et al., 1988) and may provide a reliable antemortem method of diagnosis. Muscle biopsies are preferable for detecting glycogen storage disease, even though all glycogen storage diseases are not lysosomal storage diseases. In non-lysosomal storage disease, the glycogen accumulates in the cytosol and not within lysosomal compartments.

\section{Lysosomal enzyme analysis}

Lysosomal storage diseases result from specific defects in enzymes and hence enzyme analysis is required for confirming the diagnosis. In human medicine, enzyme panels are established for rapid diagnosis and include enzymes required for digestion of glycosphingolipids and oligosaccharides. Severe depletion of enzyme activity is reported in homozygotes up to $5 \%$ of normal. Ideally, agematched control should be assayed in parallel to provide a normal set of control values. The samples for enzyme analysis include wholeblood leukocytes, biopsy samples from liver and kidney, and cultured skin fibroblasts. The techniques used for detecting enzyme activities in humans and dogs are the same (Meikle et al., 2004).

\section{Molecular genetic testing}

Identification of the genetic defect is the second definitive diagnostic method for lysosomal storage disease. With the advancement in molecular genetic testing, single-gene defects are identified in various storage diseases. Molecular genetic tests are available for canine fucosidosis, globoid cell leukodystrophy, and mucopolysaccharidosis (Skelly and Franklin, 2002).

\section{Pathology}

Affected animals are usually euthanized due to deterioration and debilitating consequences and are examined postmortem. Typical gross findings include firm brain, hepatomegaly, splenomegaly, dwarfism, and lumbar bony dysplasia. Histologically prominent and widespread neuronal vacuolation, secondary axonal degeneration, storage vacuoles containing granular materials, 
vacuolation in hepatocytes, leukocytes, renal tubular epithelium, and retinal neurons are present. The presence of brightly eosinophilic granular accumulation within the cytoplasm of neurons of an eleven-month-old English Springer Spaniel who suffered from lysosomal storage disease is given in Figure 2. Diagnosis of lysosomal storage disease involves a sequential series of steps requiring specialized techniques and expertise.

Fig 2: Accumulation of storage material in cerebellar neuron

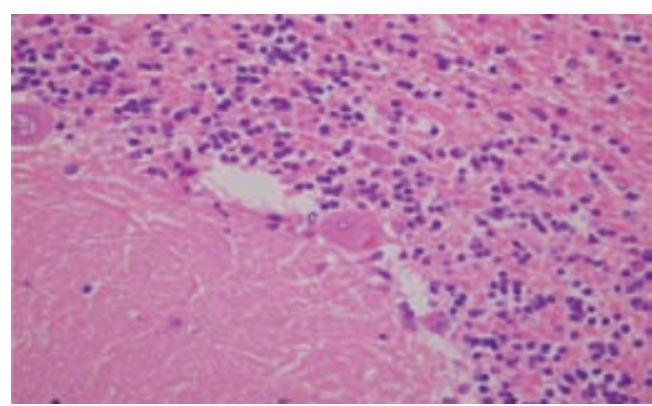

\section{Conclusion}

Lysosomal storage diseases are rare disorders and it is probable that many veterinarians are often unable to reach a specific diagnosis. Lack of testing techniques and a lack of understanding of this disease makes diagnosis difficult in veterinary practice. Awareness of this disease entity and its pathogenesis allows lysosomal storage disease to be included in the differential diagnoses in animals presenting with neurological disorders. Both acquired and inherited forms of the disease are uncommonly reported in domestic animals.

\section{Reference}

Alroy, J. and Lyons, J.A. 2014. Lysosomal storage disease. J. Inborn Errors Met. \& Screening. 2: 1-20.

Alroy, J., Orgad, U., Ucci, A. A., Schelling, S. H., Schunk, K. L., Warren, C. D., Raghavan, S. S. and Kolodny, E. H. 1985. Neurovisceral and skeletal GM1-gangliosidosis in dogs with betagalactosidase deficiency. Science, 229(4712): 470-472.
Alroy, J. and Ucci A.A. 2006. Skin biopsy: a useful tool in the diagnosis of lysosomal storage diseases. Ultrastruct. Pathol. 30(6): 489-503.

Ballabio, A. and Gieselmann, V.2009. Lysosomal disorders: from storage to cellular damage. Biochimica et Biophysica Acta (BBA)-Mol. Cell Res. 1793(4), 684-696.

De Maria, R., Divari, S., Bo, S., Sonnino, S., Lotti, D., Capucchio, M. T. and Castagnaro, M. 1998. Beta-galactosidase deficiency in a Korat cat: a new form of feline GM1gangliosidosis. Acta Neuropathol. 96(3): 307-314.

Ferreira, C. R. and Gahl, W. A. 2017. Lysosomal storage diseases. Transl. Sci. Rare Dis. 2(1-2): 1-71.

Jezyk, P.F., Haskins, M.E. and Newman, L.R. 1986. Alpha-mannosidosis in a Persian cat. J. Am. Vet. Med. Assoc., 189(11): 1483-1485.

Jolly, R. D. and Walkley, S. U. 1997. Lysosomal storage diseases of animals: an essay in comparative pathology. Vet. Pathol. 34(6): 527-48.

Kumar V., Abbas A.K., Aster J.C. and Fausto N. 2010. Robins and Cotran (editors).Pathologic Basis of Disease.8th Ed. Saunders, Philadelphia, 1464p.

Luzio, J.P., Pryor, P.R. and Bright, N.A. 2007. Lysosomes: fusion and function. Nat. Rev. Mol. Cell Biol.. 8(8): 622-32.

Marques, A.R.A. and Saftig P. 2019. Lysosomal storage disorders - challenges, concepts and avenues for therapy: beyond rare diseases. J. Cell Sci. 132(2).

Meikle, P.J., Fietz, M.J. and Hopwood, J.J. 2004. Diagnosis of lysosomal storage disorders: current techniques and future directions. Expert Rev. Mol. Diagn. 4(5): 677-691.

Saftig, P. and Klumperman, J. 2009. Lysosome biogenesis and lysosomal membrane 
proteins: trafficking meets function. Nat. Rev. Mol. Cell Biol. 10(9): 623-635.

Skelly, B. J. and Franklin, R. J. 2002. Recognition and diagnosis of lysosomal storage diseases in the cat and dog. J. Vet. Intern. Med. 16(2): 133-41.

Vicini, D. S., Wheaton, L. G., Zachary, J. F. and Parker, A. J. 1988. Peripheral nerve biopsy for diagnosis of globoid cell leukodystrophy in a dog. J. Am. Vet. Med. Assoc. 192(8): 1087-1090.
Wenger, D. A., Victoria, T., Rafi, M. A., Luzi, P., Vanier, M. T., Vite, C., Patterson, D. F. and Haskins, M. H. 1999. Globoid cell leukodystrophy in cairn and West Highland white terriers. $J$ Hered. 90(1): 138- 142.

Walkley, S.U. 2009. Pathogenic cascades in lysosomal disease-Why so complex? J. Inherit. Metab. Dis. 32: 181-189. 